PF 2019 (LXXIII): 245-260

\author{
ALICJA MATCZUK \\ Instytut Informacji Naukowej i Bibliotekoznawstwa \\ Uniwersytet Marii Curie Skłodowskiej w Lublinie \\ plac Marii Curie-Skłodowskiej 4a, 20-031 Lublin \\ e-mail: alicjamatczuk@gmail.com \\ ORCID ID: 0000-0001-7225-3996
}

\title{
ADAM ANTONI KRYŃSKI JAKO TWÓRCA BIBLIOGRAFII JEZYKOZNAWSTWA POLSKIEGO
}

SŁOWA KLUCZOWE: Adam Antoni Kryński, językoznawstwo polskie, bibliografia, XIX-XX wiek

KEYWORDS: Adam Antoni Kryński, Polish linguistics, bibliography, $19^{\text {th }}$ and $20^{\text {th }}$ centuries

\section{ADAM ANTONI KRYŃSKI - CREATOR OF POLISH LINGUISTICS’ BIBLIOGRAPHY}

\begin{abstract}
Adam Antoni Kryński developed interest in bibliography in Szkoła Główna in Warsaw, where he studied under the supervision of an distinguished philologist and bibliographer, Józef Przyborowski. Kryński started to be an active bibliographer with the establishment of "Prace Filologiczne" (1885), the first Polish journal on linguistics. In the same year, Kryński and Karol Appel announced Przegląd bibliograficzny prac naukowych o jezyku polskim, a listing of linguistic works by Polish and foreign authors and works on auxiliary sciences, published mainly in the $19^{\text {th }}$ century. Comprehensive, critical and advising content annotations were specific for the listing of Kryński and Appel. Thanks to Kryński's initiative, the current bibliography of Polish linguistics was being published in 1887-1916. Together with Stanisław Szober Kryński published also bibliography of Polish linguistic works for 1915-1925 (1926). Creation of Polish bibliography of linguistics remains an excellent merit of A.A. Kryński for the history of Polish linguistics and history of Polish bibliography.
\end{abstract}

Z dotychczasowych prac o Adamie Antonim Kryńskim (1844-1932) poznać możemy doskonale sylwetkę językoznawcy i człowieka, drogę życia i dorobek 
naukowy jednego z czołowych humanistów XIX i XX w., profesora Uniwersytetu Warszawskiego i Lwowskiego, członka Akademii Umiejętności, organizatora życia naukowego. Tylko wąskiemu kręgowi badaczy kojarzy się on z działalnością bibliograficzną, podobnie tylko nielicznym znany jest jego wkład w rozwój polskiej bibliografii językoznawczej (Iwańczyk 2013, s. 123-137; Matczuk 2014, s. 59).

W niniejszym szkicu starano się ukazać oblicze Adama A. Kryńskiego jako bibliografa, przedstawić genezę kształtowania się jego zainteresowań bibliograficznych, a nade wszystko zaprezentować jego twórczość bibliograficzną w zakresie językoznawstwa polskiego, ze szczególnym zwróceniem uwagi na okoliczności powstania prac oraz ich rozwój metodyczny.

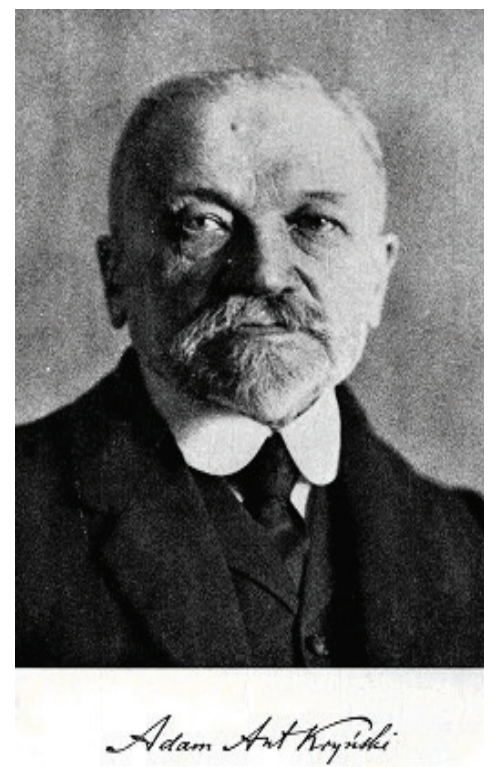

Źródło: Antoni Andrzej Kryński. Życie i prace. Przedstawił Stanisław Szober. Warszawa 1934

Zainteresowanie bibliografią wyniósł Kryński ze studiów w Szkole Głównej w Warszawie. Jak wielu absolwentów tej uczelni i tego pokolenia, był on głęboko przekonany, że podejmowanie prac na tym polu, oprócz rejestracji piśmiennictwa polskiego, stanowi obowiązek patriotyczny. W nich upatrywano narzędzia skutecznej samoobrony przed zatraceniem pamięci i kultury wiadomości o dawnym piśmiennictwie narodu, a zarazem uznawano je za podstawę wszelkich badań naukowych.

Niemałą rolę w kształtowaniu światopoglądu Kryńskiego, jego stosunku do zabytków piśmiennictwa polskiego, opinii o dziełach bibliograficznych jako podstawy wszelkich studiów i badań humanistycznych odegrał niewątpliwie profesor 
historii literatury polskiej, gramatyki i języka polskiego w Szkole Głównej oraz naczelny bibliotekarz biblioteki tejże uczelni - Józef Przyborowski (Motz 1972, s. 724-725). Ten znawca staropolszczyzny i bibliografii polskiej był także jednym z trzech uczonych (oprócz Władysława Nehringa i Antoniego Małeckiego), których zasługą było wprowadzenie metody filologicznej do badań historycznoliterackich. Z ich to inspiracji zaczęło się planowe badanie źródeł (rękopisów, rzadkich druków), krytyczne wydawanie unikatów, co wpłynęło na rozbudzenie zainteresowań bibliografią i opracowaniami bibliograficznymi (Korpała 1969, s. 153). Przyborowski był bibliografem publikującym, w dorobku miał szereg prac bibliograficznych opracowanych według zasad metody filologicznej, m.in. Wiadomość o życiu i pismach Jana Kochanowskiego (1857), Jana Kochanowskiego „Pieśn o potopie”. Studium bibliograficzne (1876).

Przyborowski jako uczony, bibliograf i wykładowca był wzorem dla młodego studenta, zwłaszcza że dokonania naukowe profesora budziły powszechne uznanie, a olbrzymia wiedza i erudycja w zakresie bibliografii zjednały mu popularność i podziw. Tak pisał o nim Kryński z okazji 25-lecia pracy naukowej swojego mistrza:

Pod względem znajomości bibliografii polskiej zwłaszcza wieku XVI, wątpić można, czy znajdzie się ktoś u nas, mogący stanąć na równi z profesorem Przyborowskim. W ocenianiu zaś szczegółów, dotyczących pierwszych druków polskich, wydań dzieł najrzadszych, oraz dzieł Kochanowskiego, jest znawcą bezwarunkowo najbieglejszym (Kryński 1882, s. 162).

Niewykluczone również, że Kryński znał osobiście Karola Estreichera, zastępcę Przyborowskiego w Bibliotece Szkoły Głównej, a już na pewno wiedział o jego pracy nad retrospektywną Bibliografia polską. Mógł też uczęszczać na wykłady z bibliografii prowadzone przez Estreichera w Szkole Głównej w latach 1865-1868.

Pracując niemal całe życie na terenie Warszawy, w warunkach bardzo niepomyślnych dla pracy bibliograficznej, szczególnie w ostatniej ćwierci XIX w., potrafił Kryński rozbudzić w szerszych kołach inteligencji zainteresowanie bibliografią językoznawczą oraz przekonać o jej doniosłości dla polskiego życia naukowego i kulturalnego.

Działalność naukową w zakresie bibliografii rozpoczął Kryński w 1874 r. Zadebiutował Przeglądem piśmiennictwa zagranicznego z zakresu językoznawstwa, który opublikował w piśmie „Niwa”, dając tym samym początek rejestracji bibliograficznej prac z tej dziedziny naukowej w Polsce. Jednak aktywność bibliograficzną rozwinął dopiero z chwilą powstania w $1884 \mathrm{r}$. czasopisma „Prace Filologiczne”, którego był pomysłodawcą i współzałożycielem (Rudnicka 2006, s. 113-114). Zgodnie z koncepcją pisma ważne ogniwo w systemie informacji 
o piśmiennictwie językoznawczym miały stanowić, oprócz recenzji i sprawozdań, zestawienia bibliograficzne (Kryński 1885, s. [5]). Spisom bibliograficznym wyznaczył Kryński znaczne miejsce w „Pracach”, wskazując, iż racjonalne zorganizowanie bibliografii językoznawczej stanowi fundament rozwoju tej dyscypliny. Był jednocześnie przekonany, iż należy rozpocząć od bibliografii retrospektywnej, a dopiero później przystąpić do ogłaszania zestawień o charakterze bieżącym. W tym czasie, kiedy trwały przygotowania do zorganizowania „Prac” (pomysł zrodził się w 1882 r.), Kryński wraz z Karolem Applem przystąpili do gromadzenia materiału bibliograficznego na temat języka polskiego. W liście z 7 września 1884 r. Kryński donosił Janowi Karłowiczowi o przystąpieniu do druku pierwszego tomu „Prac” oraz jego zawartości, informując, że jeden z tekstów stanowi

(...) bibliografia prac z zakresu językoznawstwa polskiego z ostatniego dwudziestolecia wraz z krótką ich oceną i ze wzmiankami o recenzjach, jakie udało mi się wyszukać wraz z Apelem po czasopismach poważniejszych (Rudnicka 2006, s. 115-116).

Można sądzić, że z powodu opóźniającego się druku tego tomu autorzy rozszerzyli ramy chronologiczne spisu, włączając starsze piśmiennictwo, które ukazało się przed rokiem 1860.

Ostatecznie zestawienie bibliograficzne Kryńskiego i Appla ukazało się w drugiej połowie 1886 r. w tomie pierwszym „Prac” zawierającym łącznie zeszyt drugi i trzeci. Nosiło ono tytuł Przegląd bibliograficzny prac naukowych o języku polskim. Praca wyszła również jako odbitka w tym samym roku, ale data cenzury (10 lipca 1886 r.) świadczy, że wydrukowano ją zapewne wcześniej niż wspomniane zeszyty, które urząd kontroli zatwierdził 16 września 1886 r. Ukazała się ona nakładem warszawskiej firmy księgarsko-wydawniczej Edwarda Wendego i Sp. (Estreicher jr. 1959, s. 168). Zanim jednak do tego doszło, Kryński zapewne musiał przezwyciężyć trudności cenzury rosyjskiej związane z zawartością i tytułem dzieła. Wiadomo bowiem, że praktycznie przez cały okres rusyfikacji lat 80. i 90. XIX w. cenzura starała się nie dopuszczać do druku tytułów zawierających wyrazy naród, polski, zmieniając je na kraj, krajowy. Ograniczenia tematyczne i językowe dotyczyły oczywiście także opracowań bibliograficznych (Matczuk 2017, s. 89-90).

Bodźce, które skłoniły autorów do opracowania Przeglądu, były dwojakiej natury. Niewątpliwie główną rolę odegrały tutaj potrzeby naukowe. Był to bowiem czas konstytuowania się językoznawstwa jako samodzielnej dziedziny naukowej i wprowadzania jej na uniwersytety (Bajerowa 1987, s. 802). Procesowi temu towarzyszył rozwój piśmiennictwa językoznawczego (Urbańczyk 1993, s. 94-101), co rodziło z kolei potrzebę źródeł informacji o tym piśmiennictwie, przede wszystkim w formie odpowiednich bibliografii. Piszą o tym autorzy w przedmowie: 
W ostatnich paru dziesiątkach lat w badaniach nad językiem polskim zapanował kierunek naukowy, a odnośna literatura przybrała takie rozmiary, że do rozejrzenia się w niej już dziś pożądanym być może "przewodnik bibliograficzny«. Przedsięwzięta tu przez nas praca ma właśnie uczynić zadość tej potrzebie. Ułożenie podobnego przewodnika podejmujemy zresztą nie tyle dla samodzielnych znawców przedmiotu, ile dla szerszego koła czytelników, przeważnie ze sfery nauczycielskiej, tudzież dla początkujących pracowników na polu naukowym. Chodziło nam przede wszystkim o dostarczenie czytelnikom podręcznych wskazówek, gdzie i czego w danej kwestii szukać wypada; zaznaczając zaś, co zrobiono już w nauce języka polskiego, pragnęlibyśmy jednocześnie przypomnieć, co jeszcze zrobić można i trzeba... (Appel, Kryński 1886, s. 541).

Drugi cel miał wyraźnie motywację patriotyczną. Bibliografia powstała w środowisku warszawskim w okresie wzmożonych represji zaborcy. Jej autorzy zakładali, iż dokonana przez nich rejestracja dorobku rodzimej nauki na temat języka polskiego jest równocześnie afirmacją odrębności i dojrzałości kultury polskiej. Przegląd stanowi więc przykład wykorzystania materiałów bibliograficznych dla celów walki politycznej.

Piśmiennictwo zarejestrowane w Przeglądzie obejmowało prace z zakresu językoznawstwa polskiego oraz teksty z zakresu nauk pomocniczych (fizjologia mowy, psychologia mowy, patologia mowy), co w znacznym stopniu podnosiło wartość bibliografii. Dokładniej, autorzy uwzględnili prace dotyczące językoznawstwa polskiego (we wszystkich językach), badania porównawcze dotyczące języków słowiańskich, jak również prace z zakresu językoznawstwa ogólnego (choć wyłącznie te napisane przez autorów polskich).

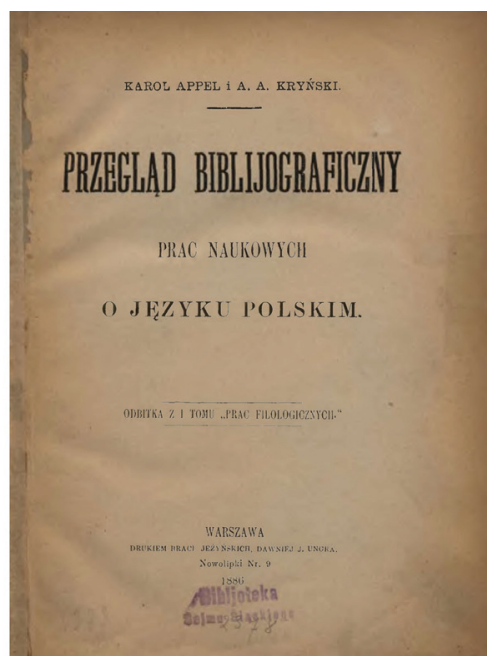

Rys. 1. Strona tytułowa odbitki Przegladu bibliograficznego prac naukowych o języku polskim. Warszawa 1886 
Przegląd jest bibliografią retrospektywną, rejestruje bowiem publikacje sięgające daleko wstecz, ale nie przekraczające 1885 r. (z wyjątkiem kilku prac wydanych w 1886 r.). Przeważa, rzecz jasna, piśmiennictwo opublikowane w XIX w., można też jednak spotkać opisy dzieł wydanych w XVII i XVIII w. Najdawniejszą pozycją podaną w bibliografii jest Thesaurus polonolatino-graecus... Grzegorza Knapskiego (Kraków 1621; wyd. 2. 1643), nie licząc przedruków homograficznych tekstów XVI-wiecznych.

Bibliografia wykazywała piśmiennictwo polskie wydane na ziemiach polskich i za granicą, niezależnie od tego, w jakim języku zostało ogłoszone. Ponadto uwzględniała prace autorów obcych, jeżeli dotyczyły one języka polskiego. Zestawieniem objęto wydawnictwa zwarte, ciągłe, artykuły z czasopism i rozprawy z dzieł zbiorowych. Praktycznie nieograniczony był także dobór materiałów pod względem piśmienniczym. Oprócz rozpraw naukowych uwzględnione zostały polemiki, recenzje, słowniki, poradniki, podręczniki. W zestawieniu figurowały też liczne opracowania tak zwanych zabytków języka polskiego (zarówno staropolszczyzny, jak i odmian terytorialnych). W Przegladzie odnotowano i scharakteryzowano - według obliczeń autorki - 510 pozycji. Liczba ta nie jest jednak miarodajna i w rzeczywistości odnotowanych prac jest znacznie więcej wskutek podawania w adnotacjach informacji bibliograficznych dotyczących innych prac na dany temat, polskich i obcych.

Autorzy podali wykaz czasopism i wydawnictw zbiorowych wykorzystanych przy opracowaniu bibliografii. Uwzględnili oni pozycje z ważniejszych polskich czasopism wydanych we wszystkich zaborach: z roczników, miesięczników i dwutygodników. W sposób szczegółowy rozpisano zawartość czasopism krakowskich: „Pamiętnika Akademii Umiejętności”, „Rozprawy i Sprawozdania z Posiedzeń Wydziału Filologicznego Akademii Umiejętności”, „ Przewodnika Bibliograficznego". Oprócz materiałów z czasopism polskich autorzy zarejestrowali artykuły z wybranych periodyków obcych (niemieckich, czeskich i rosyjskich), głównie specjalizujących się w językoznawstwie. Ogółem w Przeglądzie odnotowane zostały artykuły z 7 czasopism polskich i 19 obcych. Ponadto zamieszczono spis „Źródeł bibliograficznych” obejmujący 9 pozycji, wśród których znalazły się bibliografie, przeglądy krytyczno-bibliograficzne oraz prace zawierające bogaty materiał bibliograficzny z zakresu językoznawstwa.

Większość materiału bibliograficznego została opisana z autopsji. Świadczy o tym następujący fragment przedmowy: „Wobec szczupłych środków naukowych, jakie mogliśmy mieć pod ręką, praca nasza daleka będzie zapewne od tej dokładności, jaką radzilibyśmy jej nadać. Wiele rzeczy, dla braku danych wypadło pominąć, zamieszczamy bowiem z zasady tylko rzeczy nam znane istotnie” (Appel, Kryński 1885, s. 541). Inny dowód stanowią również obszerne adnotacje analityczno-krytyczne, o których będzie mowa w dalszej części artykułu. 
Metoda i zasady opisu bibliograficznego w Przeglądzie z reguły odpowiadały wymaganiom ówczesnej techniki bibliograficznej. Dzieła autorskie opisywano pod nazwą autora (nazwisko, imię, rzadziej inicjał), uzupełnioną niekiedy tytułem naukowym lub zawodowym. Pseudonimy i kryptonimy na ogół były rozwiązywane. Jeśli chodzi o dzieła zbiorowe, trzeba podkreślić, że odstąpiono od prawie powszechnej wówczas praktyki opisywania ich pod pierwszym rzeczownikiem tytułu, umieszczając je pod pierwszym wyrazem tytułu.

Opis zasadniczy pozycji obejmował następujące elementy: przy drukach zwartych - tytuł, podtytuł, oznaczenie wydania, pełny adres wydawniczy (miejsce wydania, nazwa nakładcy lub drukarni, rok wydania), format oraz objętość; przy publikacjach w czasopismach - cytatę wydawniczą: tytuł pisma (tylko w nielicznych przypadkach w skrócie), rok, numer tomu lub rocznika, strony, na których znajdował się tekst. Zgodnie z ówczesnym zwyczajem cytata wydawnicza ujęta była w nawias okrągły. Teksty drukowane cyrylicą były transliterowane, co należało wówczas do rzadkości, gdyż przeważnie stosowano transkrypcję.

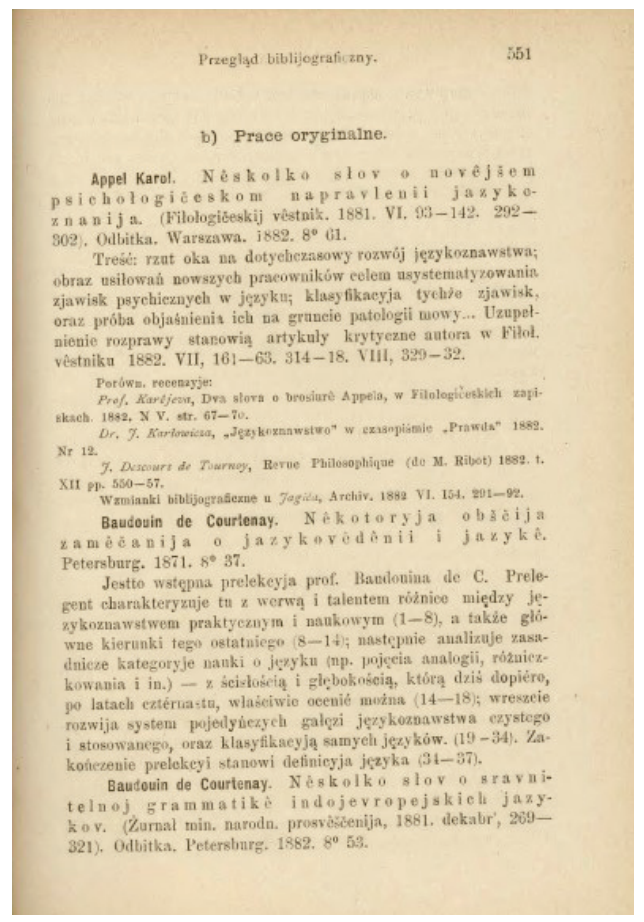

Rys. 1. Fragment Przegladu bibliograficznego prac naukowych o języku polskim

Przegląd bibliograficzny podawał coś więcej niż opis publikacji, więcej niż inne bibliografie tego rodzaju, mianowicie obszerne adnotacje, dotyczące cech wydawniczo- formalnych, a nade wszystko, treści publikacji. Te adnotacje stanowiły 
novum w bibliografii dziedzinowej, a dla badaczy były źródłem wszechstronnych wiadomości, cennych nie tylko dla językoznawcy, ale także dla historyka kultury i literatury, szczególnie w dziale pomników piśmiennictwa polskiego. Wprawdzie już wcześniej stosowano adnotacje bibliograficzne, ale ani przed Przeglądem, ani po nim nie została przygotowana bibliografia specjalna, która by opisywała $\mathrm{w}$ tak wnikliwy sposób materiał bibliograficzny. Pod tym względem stanowi on wyjątek w dziejach polskiej bibliografii dziedzinowej.

Adnotacje księgoznawcze odnosiły się do okoliczności powstania publikacji, jej losów, kolejnych wydań, przeróbek, recenzji, polemik, a także związków bibliograficznych między publikacjami.

Główna uwaga autorów Przeglądu poświęcona była tematyce opisywanych publikacji. Wynikało to $\mathrm{z}$ naczelnego założenia ideowego i naukowego, że najważniejszym zadaniem bibliografii jest zwrócenie uwagi badaczy na zagadnienia omawiane w pracach, wymienienie ważniejszych ich wątków oraz wskazanie drogi poszukiwań. Nie ograniczono się do omawiania tematyki prac, ale zwracano uwagę na jej dokumentarne znaczenie, odzwierciedlające charakterystyczne cechy epoki. Adnotacje cechowała obszerność, nierzadko drobiazgowość. Zawierały nie tylko charakterystykę tematu opisywanej publikacji, ale także element oceny, często sformułowanej na podstawie recenzji, do której autorzy odsyłali czytelnika. Uwagi nierzadko były zabarwione osobistym tonem. Często podkreślano przydatność i ważność tekstu, jak i np. jego wpływu na rozwój badań w zakresie językoznawstwa. Co więcej, w przypadku pewnych mankamentów i błędów w opisywanej pracy autorzy bibliografii zwykle starali się wytłumaczyć ich obecność. Oczywiście zdarzały się też negatywne oceny prac. Przeważnie dotyczyły one warsztatu pisarskiego lub metodologicznego, rzadziej podważały kompetencje językoznawcy na temat podjętego przez niego zagadnienia. Jak słusznie zauważa Patryk Iwańczyk, „Obecność tego typu uwag była podyktowana pragnieniem ratowania kultury polskiej zagrożonej w wyniku represyjnej polityki zaborców. Dbałość o czystość rodzimego języka niewątpliwie do takich działań się zaliczała" (Iwańczyk 2013, s. 132). Autorzy żywili nadzieję, że:

(...) sądy, wypowiedziane przedmiotowo, nie drasną zapewne nikogo, nie wywołają osobistych uraz, niechęci (Appel, Kryński 1885, s. 542).

Rozległość adnotacji treściowych nadawała Przeglądowi walory krytycznej bibliografii analitycznej i dokumentacyjnej piśmiennictwa polskiego o języku polskim. Jednocześnie stanowiła świadectwo wybitnego znawstwa literatury językoznawczej, olbrzymiej erudycji i skrupulatności autorów.

Gdy chodzi o konstrukcję Przeglądu, autorzy zastosowali układ systematyczny. Całość materiału bibliograficznego podzielona została na trzy podstawowe działy: A: Językoznawstwo ogólne, B. Językoznawstwo słowiańskie, C. Językoznawstwo 
polskie. Działy główne dzielą się na poddziały, które wyróżniono za pomocą cyfr rzymskich. Językoznawstwo ogólne dzieli się na: I. Językoznawstwo właściwe oraz II. Nauki pomocnicze (fizjologia mowy, psychologia, patologia). Z kolei Językoznawstwo słowiańskie zawiera dwa poddziały: I. Wiadomości przygotowawcze do nauki języków słowiańskich $i$ w szczególności polszczyzny i II. Dzieła i rozprawy z zakresu gramatyki porównawczej języków słowiańskich, uwzględniających polszczyznę. Najbardziej rozbudowany był dział Językoznawstwo polskie, który składał się z następujących poddziałów: I. Gramatyki polskie (naukowe), dzieła i rozprawy z historii języka polskiego; II. Pomniki polszczyzny i ich opracowania pod wzgledem językowym (wiek XIV-XVII); III. Dialektologia podzielone na a) Badania gwar ludowych i b) Zbiory pieśni, podań ludu itp. materiały; IV. Leksykografia z uwzględnieniem etymologii; $V$. Praktyczna strona nauki języka polskiego podzielona na a) Gramatyki szkolne i b) Rozprawy o pisowni i poprawności języka. W poszczególnych działach i poddziałach zastosowano szeregowanie alfabetyczne (w obrębie autora - chronologiczne). Wyjątek stanowi dział Pomniki polszczyzny i ich opracowania pod względem językowym (wiek XIV-XVII), w którym za podstawę porządkowania pozycji przyjęto chronologię przedmiotową, tj. okresy będące przedmiotem tekstów.

Zestawienie opublikowane w „Pracach Filologicznych” nie posiadało indeksu osobowego, nie licząc tego, który odnosił się do zawartości całego pierwszego tomu czasopisma. Zastosowane rozwiązanie bardzo utrudniało użytkownikowi korzystanie z bibliografii. Autorzy mieli tego pełną świadomość, dlatego postać książkową Przeglądu wyposażyli w Wykaz nazwisk autorów, co znacznie podniosło sprawność informacyjną spisu. Z powodu braku numeracji pozycji w bibliografii wykaz odsyłał do odpowiednich stron, na których mowa była o autorach i ich dziełach.

Bibliografia zaopatrzona została w przedmowę, spis rzeczy (tylko w odbitce), wykaz czasopism i wydawnictw zbiorowych oraz źródeł bibliograficznych. Dążenie do nadania bibliografii optymalnej postaci obserwujemy w zróżnicowaniu typograficznym tekstu i układzie graficznym całej strony. Hasła autorskie wyróżniono pogrubioną czcionką, tytuły dzieł zostały wyspacjowane, recenzje złożono mniejszą czcionką. Usprawnieniu lektury i zapamiętaniu tekstu adnotacji służyło wyróżnianie kursywą przywoływanych w nich nazwisk innych autorów oraz ujmowanie w cudzysłów lub kursywę wyrazów określających nazwy pojęć, terminów. Niestety adnotacje wydrukowano tym samym stopniem czcionki jak opis bibliograficzny, co niekorzystnie wpływało na przejrzystość i czytelność spisu.

Przegląd bibliograficzny został oceniony przez środowisko naukowe i bibliograficzne jako opracowanie bardzo pożądane i użyteczne dla badań nad językiem polskim, a wykonane $\mathrm{z}$ dużą sumiennością, znawstwem i posiadające dużą wartość informacyjną. Władysław Wisłocki, historyk literatury, znany z wielkiego 
znawstwa bibliograficznego, ale też z formułowania krytycznych, surowych uwag pod adresem recenzowanych prac, bardzo wysoko ocenił opracowanie bibliograficzne Appla i Kryńskiego, zarówno w zakresie podjętego tematu, jak i metody opracowania. Wprawdzie dopatrzył się on pewnych nieścisłości i usterek merytorycznych, ale ostatecznie uznał, że:

(...) nie czynią bynajmniej ujmy niepospolitej wartości pracy naukowej, którą toż dla jej wysokich i rzetelnych zalet łaskawym względom nie tylko samodzielnym znawców przedmiotu, ale i licznym u nas starej i nowej polszczyzny miłośnikom, gorąco bardzo sobie pozwalamy (Wisłocki 1886, s. 241).

Entuzjastycznie o dziele wypowiadał się Szymon Matusiak, dialektolog i folklorysta, podkreślając jego wielką przydatność w badaniach naukowych. Pisał on:

Pochwały tu zbyteczne, praca sama się zaleca. O ile nam wiadomo, tego rodzaju pracy nie posiada żadna z literatur słowiańskich (Matusiak 1887 s. 268-269).

Z należytym uznaniem do dzieła Appla i Kryńskiego odnieśli się także potomni. Stanisław Ptaszycki uważał, że „Bibliografia ma również bardzo ważne znaczenie dla historii literatury szczególnie w dziale pomników polszczyzny" (Ptaszycki 1920, s. 127), natomiast Jerzy Starnawski uznał za ważne osiągnięcie Przeglądu instruktywne adnotacje (Starnawski 1982, s. 245).

Odczuwana coraz wyraźniej potrzeba bieżącej informacji o piśmiennictwie z zakresu językoznawstwa polskiego sprawiła, iż w roku 1887, z inicjatywy A.A. Kryńskiego, rozpoczęto ogłaszanie bibliografii bieżącej w „Pracach Filologicznych”. Publikowana była ona w odstępach paroletnich, uzależnionych od ukazywania się tomów czasopisma. Pierwsze zestawienie autorstwa K. Appla i A.A. Kryńskiego zostało opublikowane w 1887 r. (t. 2), następnie w latach 1893-1911 (t. 4-7) Bibliografie, Bibliografie prac językoznawczych lub Wiadomości bibliograficzne podawał Kryński, po czym w latach 1913-1916 (t. 8) wspólnie z synem Mirosławem ${ }^{1}$. Warto podkreślić, że poczynania Kryńskiego w dziedzinie

1 Mirosław Zbigniew Kryński (1886-1917) - polski filolog, wykładowca Towarzystwa Kursów Naukowych w Warszawie, członek Towarzystwa Naukowego Warszawskiego. Pracował jako profesor języka polskiego i łacińskiego w Szkole Agronomicznej E. Rontalera we Lwowie (1901-1911), od 1911 pełnił tam funkcję inspektora (do 1916 r.). Od 1916 r. wykładał językoznawstwo porównawcze, gramatykę języka polskiego i filologię wschodniosłowiańską w Towarzystwie Kursów Naukowych w Warszawie. W 1917 r. został członkiem Towarzystwa Naukowego Warszawskiego i otrzymał propozycję objęcia Katedry Sanskrytu na Uniwersytecie Warszawskim; zmarł wskutek choroby serca, nie zdążywszy skorzystać z tej oferty (Zob. „Rocznik Towarzystwa Naukowego Warszawskiego" 10, s. 186-189). 
bibliografii językoznawstwa należały do najwcześniejszych prób zorganizowania polskiej bieżącej bibliografii dziedzinowej².

Te niewielkie objętościowo zestawienia, drukowane w odcinkach, podawały opisy pozycji za lata 1885-1915. W porównaniu z bibliografią retrospektywną widać spore różnice w zakresie doboru i opisu publikacji. Ograniczono się głównie do rejestracji książek, odbitek, nadbitek, czasem wykazywano zawartość czasopism naukowych. Opis bibliograficzny był zwięzły (w nazwach autorów były zwykle inicjały imion, nie podawał nakładcy). Zaniechano dość szybko, bo od tomu 3, obszernych krytycznych adnotacji księgoznawczych i treściowych. Odtąd pojawiały się one sporadycznie i najczęściej w formie krótkich notek. Było to zresztą zgodne z praktyką bibliograficzną ówcześnie stosowaną w bibliografiach bieżących (Matczuk 2014, s. 271). Ze względu na skąpą liczbę publikacji w zestawieniach nie wydzielono odrębnych działów, ograniczając się do tworzenia grup rzeczowych, skupiających pozycje według tematyki. Grupy te jednak nie miały oddzielnych nagłówków, nie były również oddzielone kreskami (jak w bibliografii retrospektywnej), co niezmiernie utrudniało orientację.

Zestawień tych Kryński jednak nigdy nie traktował jako wystarczających do badań językoznawczych. Był przekonany o konieczności zorganizowania pełnej, systematycznej bibliografii bieżącej polskich prac językoznawczych. Do zrealizowania przedsięwzięcia dojść miało jednak dopiero pod koniec lat 20. XX w.

Po przerwie wojennej ukazał się w 1920 r. tom 9 „Prac Filologicznych”, który jako jedyny w historii pisma pozbawiony był bibliografii. Wydanie tego tomu, przerwane przez wojnę i do końca doprowadzone przez Kryńskiego, zawierało Historię Aleksandra w tłumaczeniu Leonarda Bonieckiego z roku 1510 wydaną z rękopisu przez jego przedwcześnie zmarłego syna - Mirosława Kryńskiego. Wraz z jego odejściem środowisko językoznawcze pozbawione zostało dobrze zapowiadającego się bibliografa, a Kryński stracił nie tylko bliską osobę, ale też współpracownika, którego widział zapewne jako swojego następcę i kontynuatora w swojej dotychczasowej swojej działalności bibliograficznej w dziedzinie językoznawstwa. Mimo tragedii rodzinnej Kryński nie zaprzestał działalności naukowej oraz nie zarzucił myśli o kontynuowaniu bibliografii językoznawczej.

Do pracy nad bibliografią Kryński zaprosił Stanisława Szobera³. Znał go jeszcze z czasów, kiedy był nauczycielem języka francuskiego w gimnazjum, do

2 Od 1878 r. wychodził Przegląd piśmiennictwa lekarskiego polskiego, w latach 1878-1882 ukazywała się bieżąca Bibliografia z zakresu historii literatury i oświaty w Polsce („Archiwum Do Dziejów Literatury i Oświaty w Polsce”) oraz w latach 1878-1880 Bibliografia historii geografii historycznej i historii prawa polskiego („Archiwum Komisji Historycznej AU”), obie autorstwa Władysława Wisłockiego.

3 Stanisław Szober (1879-1938) - polski językoznawca, pedagog i leksykograf; od 1919 r. profesor Uniwersytetu Warszawskiego, najpierw języka polskiego, potem językoznawstwa indoeuropejskiego. 
którego uczęszczał Szober. Po wyjeździe Kryńskiego do Lwowa w 1908 r. Szober objął po nim wykłady w Towarzystwie Kursów Naukowych (później Wolnej Wszechnicy), a w 1919 r. otrzymał Katedrę Języka Polskiego Uniwersytetu Warszawskiego, którą wcześniej kierował Kryński.

W 1926 r. w tomie 10 „Prac” wspólnie ogłosili retrospektywną Bibliografię polskich prac językoznawczych za lata 1915-1925. Jak podkreślali autorzy we wstępie, „o polskości językoznawczych prac naukowych mogłyby rozstrzygać trzy kryteria: 1) autorstwa, 2) język wykładu, 3) język będący przedmiotem roztrząsań badawczych. Zbierać do tomu 10-go materiały bibliograficzne za długi okres ostatnich lat jedenastu, ograniczyliśmy się na razie tylko do dwóch pierwszych kryteriów"(Kryński, Szober 1926, s. 382). Uwzględniono zatem tylko prace autorów polskich napisane w języku polskim i obcym bez względu na miejsce wydania, jak i prace autorów obcych napisane w języku polskim. Zgodnie z wcześniejszą zapowiedzią w tomie następnym autorzy odnotowywali również prace cudzoziemców napisane w języku obcym, jeżeli dotyczyły języka polskiego.

W stosunku do wcześniejszych zestawień istotnemu poszerzeniu uległ w $B i$ bliografii zasięg wydawniczo-formalny; przedmiotem opisu stały się nie tylko pozycje książkowe, lecz również artykuły z czasopism naukowych (polskich i obcych) oraz artykuły z prasy codziennej, tygodników. Sprawiło to, iż bibliografia dawała pełny obraz dokonań w dziedzinie językoznawstwa polskiego. Dobór materiału pod względem piśmienniczym przedstawiał się bogato. Zestawienie rejestrowało rozprawy naukowe, podręczniki, słowniki, polemiki, recenzje, a także wydania krytyczne tekstów literackich i ludowych. Liczyło ono 566 pozycji (ustalenie liczby opisów ułatwia zastosowanie numeracji ciągłej w obrębie całego zestawienia).

W Bibliografii zastosowano opis bibliograficzny skrócony. Użytkownik często znajdzie więc jedynie niezbędne informacje potrzebne do identyfikacji publikacji.

Opis zasadniczy pozycji uwzględniał następujące elementy: przy książkach - tytuł, podtytuł, nazwę i numer serii, adres wydawniczy, liczę stron, format; przy publikacjach z czasopism - cytatę wydawnicza: akronim tytułu pisma, oznaczenie tomu, miejsce i rok wydania. Artykuły z czasopism naukowych z reguły były wyraźnie uboższe w informacje bibliograficzne aniżeli w przypadku artykułów z dzienników.

Od 1938 r. członek Polskiej Akademii Umiejętności. Za najwybitniejsze dzieło Szobera uchodzi Gramatyka języka polskiego (1914-1916, wyd. 2 zmienione 1923, 1931), wielokrotnie przedrukowywana po śmierci autora. 

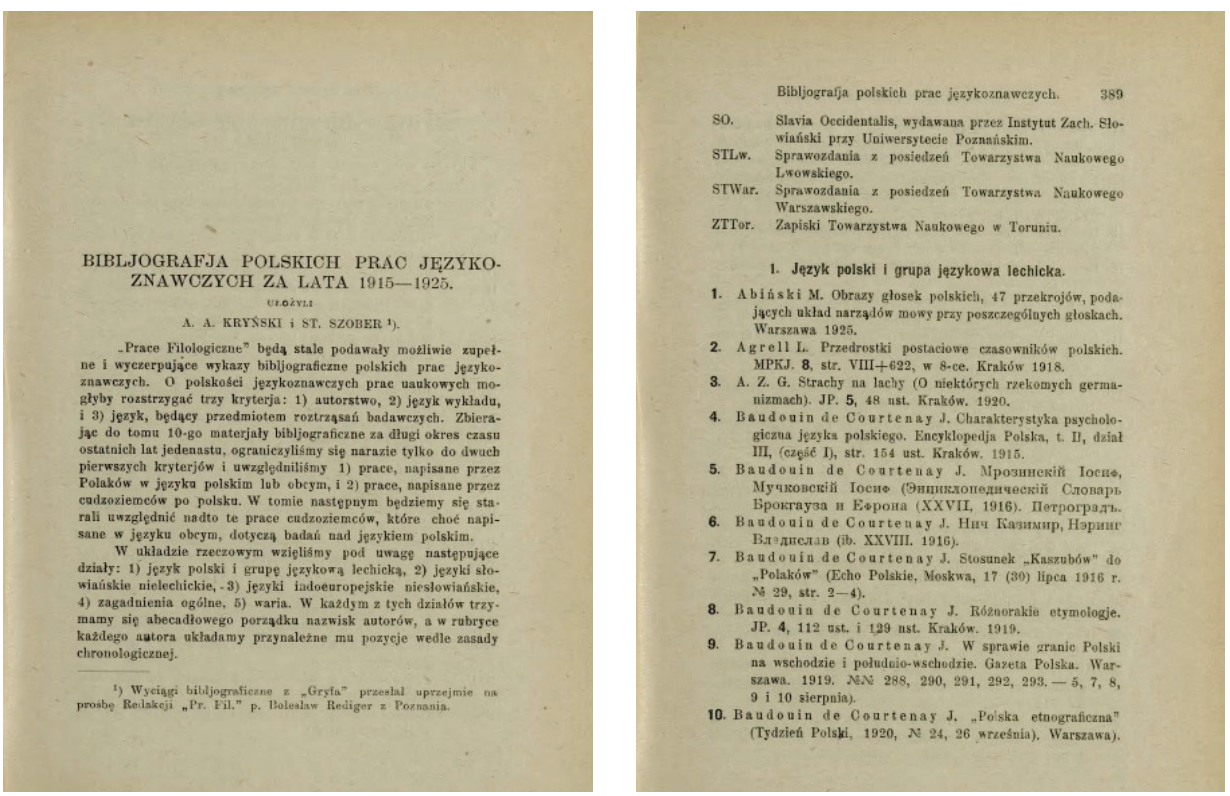

Rys. 2. Strona tytułowa i fragment Bibliografii polskich prac językoznawczych 1915-1925. „Prace Filologiczne”, t. 10 (1926)

W przypadku informowania o lokalizacji tekstu zamieszczonego w dziele zbiorowym, jak i artykułu w czasopiśmie, autorzy zestawienia konsekwentnie wstrzymują się od precyzyjnego oznaczania stron „od... do...”, w zamian podając numer pierwszej strony „nst” („i następne”). Było to poważne utrudnienie dla osoby korzystającej z bibliografii. Zmusza ją to niepotrzebnie do bezpośredniego zapoznania się z publikacją tylko po to, aby dowiedzieć się, na ile obszerny jest w rzeczywistości opisywany artykuł czy rozprawa. Natomiast widoczne były, w porównaniu z wcześniejszymi zestawieniami, większe starania o ustalenie autorów ukrywających się pod pseudonimami i kryptonimami. W opisie dzieł drukowanych cyrylicą utrzymano alfabet oryginalny, co w bibliografiach z warszawskim adresem wydawniczym było dość częstym zjawiskiem aż do drugiej wojny światowej (Matczuk 2014, s. 267). Stanowiło to efekt roli i znaczenia języka rosyjskiego na tym obszarze.

Wyjątkowo opis bibliograficzny uzupełniały adnotacje. Ogólnie można stwierdzić, że adnotacji było zbyt mało, szczególnie przy opisach artykułów z prasy periodycznej.

Całość materiału rozdzielono na pięć działów: I. Język polski i grupa językowa lechicka; II. Języki słowiańskie nielechickie; III. Języki indoeuropejskie niesłowiańskie; IV. Zagadnienie ogólne; V. Varia. W obrębie poszczególnych działów posłużono się szeregowaniem alfabetycznym, a w ramach poszczególnych haseł autorskich pozycje uporządkowano chronologicznie. 
Sprawność informacyjną Bibliografii obniżał brak osobnego indeksu autorskiego skupiającego twórczość poszczególnych autorów, których prace rozproszone były w różnych miejscach zestawienia. Niewątpliwie indeks taki stanowiłby nieocenioną pomoc dla użytkownika bibliografii.

Co się tyczy warstwy typograficznej Bibliografii, to nie budzi ona większych zastrzeżeń. Zastosowanie pogrubionej czcionki dla wyróżnienia nazw działów, numeracji pozycji, oznaczenia tomów poszczególnych czasopism oraz druku rozstrzelonego dla oznaczenia hasła autorskiego lub tytułowego wpływa na przejrzystość i czytelność tekstu bibliograficznego.

Bibliografia Kryńskiego i Szobera wykazywała znaczący postęp metodyczny w stosunku do wcześniejszych zestawień bieżących. Widoczny był on w przyjętych zasadach doboru materiału, jego opisie i układzie. Zestawienie to nie wzbudziło większego zainteresowania w ówczesnym środowisku naukowym i przeszło niezauważenie.

Niewątpliwą zasługą Kryńskiego był zachęcenie Szobera do kontynuowania bibliografii językoznawczej, można więc powiedzieć, że zarówno bezpośrednio, jak i pośrednio przyczynił się do jej rozwoju. Szober ogłosił Bibliografię polskich prac językoznawczych za lata 1926-1931 i 1932-1935 - wspólnie ze swoją uczennicą Haliną Konecznąa ${ }^{4}$ Bibliografia została oparta na tych samych zasadach, co zestawienie za lata 1915-1925. Podobny był dobór materiałów i układ zestawienia, jedynie w 1931 r. dodano dział 5: Biografie, bibliografia, historia językoznawstwa i 7: Uzupetnienia. Również forma opisu bibliograficznego nie uległa większym zmianom.

Zapoczątkowanie prac nad bibliografią językoznawstwa polskiego w warunkach szczególnie ciężkich dla nauki polskiej pozostanie na zawsze w historii językoznawstwa polskiego i historii bibliografii trwałą zasługą A.A. Kryńskiego. Dzięki jego inicjatywie, staraniom i pracy udokumentowany został polski dorobek wydawniczy w zakresie językoznawstwa do roku 1935. Kryński doceniał funkcje i walory bibliografii w badaniach językoznawczych. Swoją postawą pokazał, że nie może być rozwoju nauki o języku bez odpowiednich środków pomocniczych, do których prócz właściwych warsztatów naukowych, jakim są archiwa i biblioteki, należy także dobrze opracowana bibliografia, a w szczególności językoznawcza, stanowiąca klucz do piśmiennictwa. Jego prace były odpowiedzią na wyraźne potrzeby warsztatów naukowych. Wpłynęły one ożywczo na rozwój polskiego językoznawstwa (Urbańczyk 1993, s. 99).

4 Halina Koneczna (1899-1961) w latach 1920-1926 studiowała na Uniwersytecie Warszawskim polonistykę i slawistykę. W 1927 r. obroniła pracę doktorską pt. Dialekt Księstwa Łowickiego, której promotorem był S. Szober, po czym wyjechała do Paryża jako stypendystka Funduszu Kultury Narodowej. Po powrocie rozpoczęła pracę w Katedrze Języka Polskiego UW. W 1934 r. habilitowała się. Po wojnie podjęła pracę na UW (Zob. Jędrzejczyk 2010, s. 1-4). 
Zapoczątkowane przez Kryńskiego prace na polu bibliografii językoznawstwa polskiego rozpowszechniły się po drugiej wojnie światowej (Niemkiewicz 2000, s. 50-61). Bibliografię z tego zakresu dla okresu powojennego (1948-1970) zestawił poza granicami Polski Józef Trypućko, związany od 1940 r. z uniwersytetem w Uppsali. Regularne bieżące przeglądy bibliograficzne zaczęły prowadzić takie czasopisma, jak: „Biuletyn Polskiego Towarzystwa Językoznawczego”, „Językoznawca”, „Poradnik Językowy”.

\section{Bibliografia}

Appel, K., Kryński, A.A. (1886). Przegląd bibliograficzny prac naukowych o języku polskim, Prace Filologiczne, 1, 541-714. Odbitka. Warszawa: Druk Braci Jeżyskich.

Estreicher, K. (1959). Bibliografia polska XIX stulecia. T. 1 - Litera A. Wyd. 2. Kraków: Nakładem Uniwersytetu Jagiellońskiego.

Iwańczyk, P. (2013). Co kryje w sobie pierwszy tom „Prac Filologicznych”? Polska bibliografia językoznawcza w dobie zaborów. W: J. Ignatowicz-Skowrońska, M. Kobus (red.), Glottodydaktyka polonistyczna. Materiały z konferencji naukowej „Stereotypy w nauczaniu języka polskiego jako obcego" (123-137). Szczecin: Wydawnictwo Zapol.

Jędrzejczyk, D. (2010). Księżacka patriotka, Łowiczanin. Kwartalnik Historyczny, 1, 1-4.

Korpała, J. (1969). Dzieje bibliografii w Polsce. Warszawa: Stowarzyszenie Bibliotekarzy Polskich.

Kryński, A. A. (1882). Józef Przyborowski, Tygodnik Ilustrowany, 13, 162.

Kryński, A.A. (1885). Wstęp, Prace Filologiczne, 1, [5].

Kryński, A.A., Szober, S. (1925). Bibliografia polskich prac językoznawczych za lata 1915-1925, Prace Filologiczne, 10, 387-430.

Matczuk, A. (2014). Polskie bibliografie nauk humanistycznych i społecznych. Historia $i$ metodyka. Lublin: Wydawnictwo UMCS.

Matczuk, A. (2017). Potyczki bibliografów z cenzurą w okresie zaborów, Folia Torunensia, $17,75-103$.

Matusiak, Sz. (1887). Przegląd bibliograficzny prac o języku polskim, Przegląd Powszechny, 2, 268-269.

Motz, W. (1972). Przyborowski Józef. W: J. Treichel (red.), Słownik pracowników książki polskiej. Warszawa: Państwowe Wydawnictwo Naukowe.

Niemkiewicz, E. (2000). Bibliografia bibliografii językoznawstwa polskiego. Lublin: Towarzystwo Naukowe KUL.

Nitsch, K. (1935). Appel Karol (1857-1930). W: Polski słownik biograficzny (145-146).

T. 1. Kraków: Polska Akademia Umiejętności. 
Ptaszycki, S. (1920). Encyklopedia nauk pomocniczych historii i literatury polskiej. Lublin: nakładem Uniwersytetu Lubelskiego (KUL).

Rudnicka, E. (2006). O powstaniu „Prac Filologicznych” w kontekście dziewiętnastowiecznej prasy językoznawczej - z listów Adama A. Kryńskiego do Jana Karłowicza w okresie 1879-1887, Poradnik Językowy, 10, 111-118.

Urbańczyk, S. (1993). Dwieście lat polskiego językoznawstwa (1751-1950). Kraków: Wydawnictwo „Secesja”.

Starnawski, J. (1982). Warsztat bibliograficzny historyka literatury. Wyd. 3. Warszawa: Państwowe Wydawnictwo Naukowe.

Ś.p. Mirosław Zbigniew Przegonia-Kryński. (1917). Rocznik Towarzystwa Naukowego Warszawskiego, 10, 186-189.

Wieczorkiewicz, B. (2016). W: P. Salwa, A.K. Wróblewski (red.), Portrety uczonych. Profesorowie Uniwersytetu Warszawskiego 1915-1945. M-Ż (282-288). Warszawa: Wydawnictwa Uniwersytetu Warszawskiego.

Wisłocki, W. (1886). Przewodnik Bibliograficzny, 12, 241.

\section{Streszczenie}

Zainteresowania bibliografią Adam Antoni Kryński wyniósł ze Szkoły Głównej w Warszawie, gdzie studiował pod kierunkiem m.in. Józefa Przyborowskiego, wybitnego filologa i bibliografa. Aktywność bibliograficzną rozwinął z chwilą powołania do życia czasopisma „Prace Filologiczne” (1884), pierwszego polskiego pisma językoznawczego. W tym samym roku ogłosił wspólnie z Karolem Applem Przeglą bibliograficzny prac naukowych o języku polskim, w którym ujmował prace autorów polskich i obcych z dziedziny językoznawstwa oraz publikacje $\mathrm{z}$ zakresu nauk pomocniczych, opublikowane głównie w XIX w. Charakterystyczną cechą zestawienia były obszerne adnotacje treściowe o zabarwieniu krytyczno-zalecającym. W latach 1887-1916 z inicjatywy Kryńskiego ogłaszano bieżącą bibliografię językoznawstwa polskiego. Razem ze Stanisławem Szoberem opublikował również Bibliografie polskich prac językoznawczych za lata 1915-1925 (1926). Stworzenie bibliografii językoznawstwa polskiego pozostanie na zawsze w historii językoznawstwa polskiego i historii bibliografii polskiej trwałą zasługą A.A. Kryńskiego. 